\title{
The Marine Scientific Research Legislation And The Principles To Be Subject To Foreigners In The Subjects Of Sea Creatures, Their Environment And Their Protection In Turkey Seas: Threats
}

\author{
Raziye Tanrıverdi \\ Turkey Coast Guard Antalya Group Command \\ email: rtanriverdi@sg.gov.tr
}

\begin{abstract}
There is a possibility of illegal scientific and strategic research in Turkey Seas. The comprehensive determination of the principles of marine scientific research in Turkish Seas will play an important role in terms of national security and national interests.

Marine scientific research should be regulated by law in Turkey. With the law to be regulated, diplomatic channels or to which institution to apply depending on the subject of the research, application principles, the report principles after the research, how to follow the way about the sample and material taken, legal procedure principles to be applied in case of not obtaining permission or exiting the scope of the permission, etc. should be explained.
\end{abstract}

Keywords: Marine Scientific Research; Sea Creatures; Foreigners; Turkey Seas

\section{INTRODUCTION}

The term marine scientific research is not defined in the United Nations Convention. In the convention, the research is defined within the scope of using and protection of resources and the environment, especially the environment in which the resources are located (UNCLOS, 1982: Article 240 \& UN, 2010). Marine scientific research includes bathymetry, ocean science, oceanography, marine geology etc. (UN, 2010).

Regardless of geographical region or locations, all states and competent international organizations that ratify the United Nations Convention on the Law of the Sea under the rights and authorities of other states (UNCLOS, 1982: Articles 2, $55,56,57$ and $77 \&$ EC, 2009) have the right to conduct marine scientific research and are responsible for conducting marine scientific research only for peaceful purposes in compliance with the United Nations Convention on the Law of the Sea and legal methods and tools, by complying with the principles of protecting marine creatures and their environment (UNCLOS, 1982: Articles 238 and 240; UN, 2010).
Turkey is not a party to the United Nations Law of the Sea Convention (Karapınar, 2015 \& UN, 2017). The reason why Turkey did not accept the contract is mainly in terms of the regulations regarding the compulsory jurisdiction of the width of the territorial sea and sea law disputes (Güneş, 2007). Although it does not have a negative attitude about the regulations regarding the protection of the marine environment and archaeological heritage, it is seen that it is included in a series of conventions and programs both regionally and globally (ECP, 1969, ICCAT, 1969, PEP, 1991, CBD, 1992 \& EA, 2021).

It is usually carried out research in the field of sea creatures, their environment and their protection in Turkey Seas (DPT, 2003 \& Ünal, 2011). Researches to be carried out within the scope of sea creatures, their environment and protection are examined within the scope of fisheries legislation, taking into account international agreements to which Turkey is a party. If research on sea creatures, their environment and protection is to be carried out in special environmental protection zones and military forbidden zones and security zones, permission requests are evaluated according to the legislation of these zones. 
Permits granted for research and studies are notified to the auditing institutions. Inspections are actually carried out by the Turkish Coast Guard in Turkey Seas. Preventing unauthorized activities and monitoring the activities of research vessels is carried within the scope of the Coast Guard duties (CGC, 2017: Articles: 12 and 22).

It is one of the scientific ethical rules to comply with the laws or to act in accordance with the law (Uzbay, 2006; Drew et al., 2008 \& Resnik, 2015). When the permission of scientific research is not or when permission issues are violated, illegal activity or a situation against scientific research ethics occurs (Uzbay, 2006, Drew et al., 2008, Resnik, 2015). It was pointed out that research ethics is much more than defining the difference between legal and illegal, research activities and their possible results should be evaluated independently (EC, 2013).

In Turkey and in the World various studies have been done such as scientific ethics, plagiarism and punishment (Kansu \& Ruacan, 2002, Küçük, 2003, Christians, 2005, Uzbay, 2006, Uçak \& Birinci, 2008, Bouville, 2008; Atasoy et al., 2011, Resnik, 2015), World Coast Guards and rising sea threats (Paleri, 2009), marine scientific researchs (Caflisch and Piccard 1978, Goncalves, 1982, Keyuan, 2003, Ilgaz, 2009, UN, 2010, Topsoy, 2010, Hubert, 2011; Long, 2012, Bourtzis and Rodotheatos, 2012, Hubert, 2015, Doussis, 2017, MSR, 2019), Coastal state's jurisdiction over foreign ships (Bardin, 2002), United Nations Convention on the Law of the Sea and protection of the marine environment (Güneş, 2007).

The aim of this study is to examine the marine scientific research legislation and the principles to be subject to foreigners in the subjects of sea creatures, their environment and their protection in Turkey Seas and to draw attention to the fact that the comprehensive determination of the principles of marine scientific research will play an important role in terms of national security and national interests and unauthorized marine scientific research activities can be detrimental to National Security and National interests.

\section{RESEARCH METHODS}

Turkey's national legislation has been examined.

\section{The Marine Scientific Research Legislation and the Principles to $\mathrm{Be}$ Subject to Foreigners in the Subjects of Sea Creatures, Their Environment and Their Protection in Turkey Seas}

\section{The Principles to $\mathrm{Be}$ Subject to Foreigners Who Will Do Marine Scientific Research in Turkey Seas}

In Turkey, foreign, real and legal persons or the Republic of Turkey national natural and legal persons acting on their behalf must obtain a permit for examination and scientific research in the fields of geology and nature in the sea. A guide is also allocated to those who are permitted (ICM, 1989: Article 2).

Applications to be made for permission shall contain the necessary information about the research, examination or film to be shot, the duration and place of work and the applicant (During the permit, it is taken into account whether the applicant has a study related to research and examination.) (ICM, 1989: Article 3).

In Turkey, applications other than archaeological excavations and surface explorations (It is made to the Ministry of Foreign Affairs through its own embassy in the country and if abroad, Representations of the Republic of Turkey are made) can be done in person or by mail (fax, e-mail, etc.) directly to the unit in the area where research, examination, shooting and similar work will take place or to the administration to which this unit is affiliated. Applications are finalized within five days at the latest. Other relevant authorities are informed about the applications and their results (ICM, 1989: Article 3).

Research in the sea may be permitted within the framework of the provisions of Turkey's legislation and the 
international agreements it has participated in on this matter (ICM, 1989: Article 4).

Examination, research and filming that may be harmful to our national security and national interests are not allowed. The permits of those who operate outside the work permit or whose activities are deemed harmful are canceled (ICM, 1989: Article 5).

In the examinations and researches in military forbidden zones and security zones, archaeological research and excavations; the relevant legislation of that place is applied in matters that are outside the scope of the permit specially granted to the applicant (ICM, 1989: Article 6).

Those who conduct research and analysis by obtaining permission must submit a copy of the scientific report they have prepared and a copy of the work they have published to the authority from which they obtained the permission (ICM, 1989: Article 7).

\section{Aqua Products}

The Ministry of Agriculture and Forestry is responsible for making and having it made all sorts of research on aqua products in Turkey (APL, 1971: Article 14).

Persons who are not Turkish citizens cannot enter Turkish territorial waters to catch for aqua products and are prohibited from catching of aqua products in these waters (APL, 1971: Article 21). However, foreigners who will work in survey and research works in accordance with the permission of the Ministry of Agriculture and Forestry are exempt from this provision (APL, 1971: Article 21).

If persons who are not Turkish citizens enter Turkish territorial waters for catching aqua products and they are fishing in these waters, they are fined. The catching water products and the used fish gears are seized and the transfer of the property to the public is done by the local government (APL, 1971: Article 36/i).

The Ministry of Agriculture and Forestry may allow the use of prohibited means and procedures in fishing in certain places and for a certain period of time, exclusively for the purpose of scientific and technical studies and researches (APL, 1971: Article 29).

The aqua products obtained from scientific and technical studies and researches carried out by prohibited means and methods cannot be sold under any circumstances, but destroyed if necessary (APL, 1971: Article 29). Administrative fines are imposed on those who fail to submit their information and permit documents to those concerned in a timely and correct manner (APL, 1971: Article 36/n)

The Ministry of Agriculture and Forestry, the General Directorate of Security, the Gendarmerie General Command and the Coast Guard Command are authorized to control and inspect illegal scientific research and examination activities (APL, 1971: Article 33). The controls are actually performed by the Coast Guard Command and the Ministry of Agriculture and Forestry at sea. Auditor institutions are responsible for keeping records about illegal activities, seizing the fish gears used in crime and the caught aquatic products and imposing administrative fines within the scope of their powers (APL, 1971: Article 33). Administrative fines are imposed by the highest administrative authority of the location and by the Boat Commanders of the Coast Guard Command at sea. Local authorites can delegate their authority of punishment to other officials, provided that they are announced in advance (APL, 1971: Annex Article 3).

\section{Special Environmental Protection Area}

Ministry of Environment and Urbanization, General Directorate of Conservation of Natural Assets is in charge of conducting all kinds of researches and examinations regarding natural assets, natural sites, and special environmental protection areas, having them done, monitoring, and carrying out education and awareness studies (DLO, 2011: Article 13/A-1-e).

The Council of Ministers is authorized to determine and declare a Special Environmental Protection Area. At 
the same time, it is entitled to determine the principles of protection and use in these areas, and which ministry will prepare and carry out the plans and projects. With these protection measures, it is aimed in order to make the necessary arrangements to ensure that the land and water areas which are of ecological importance in the country and the world, which are sensitive to environmental pollution and degradation, biodiversity, natural resources and related cultural resources reach future generations (EL, 1983: Article 9/d). Patara, Belek, Kekova, Fethiye-Göcek, Foça and Datça-Bozburun Environmental Protection Zones have been determined and announced with Council of Ministers Decision in Turkish sea (DCM, 1990, DCM, 2006 \& DCM, 2007). Those who want to do research in the announced Special Environmental Protection Zones should get permission from the Ministry of Environment and Urbanization, General Directorate of Protection of Natural Assets (TÜBITAK, 2016 \& DLO, 2011: Article 13/A-1-e). Those who violate the protection and usage principles determined for Special Environmental Protection Zones are fined (EL, 1983: Article 20/k).

The authority to audit whether the provisions of the Environmental Law are complied with belongs to the Ministry of Environment and Urbanization. When necessary, this authority is given by the Ministry; It is handed over to special provincial administrations, municipalities establishing environmental inspection units, the Ministry of Transport and Infrastructure, the Turkish Environment Agency, the General Directorate of Security, the Gendarmerie General Command and the Coast Guard Command (EL, 1983: Article 12).

\section{Military Forbidden Zones and Security Zones}

Military forbidden zones can be established and abolished by the President's decision. Military forbidden zones are divided into first and second degree military forbidden zones (MFZ, 1981: Article 2).
The outer boundaries of the second degree naval military forbidden zones are announced in the Official Gazette and are recorded on sea maps ((MFZ, 1981: Article 12).

Military security zones can be established and abolished by the General Staff, and private security zones around public and private organizations by the President (MFZ, 1981: Article 3). Security zones are divided into special security zones and military security zones (MFZ, 1981: Article 19).

Special security zones for the Gendarmerie General Command and the Coast Guard Command are determined by the Ministry of Internal Affairs or, if it is not deemed necessary, a separate decision is taken by the Ministry of Interior (MFZ, 1981: Article 3).

Provided that the positive opinion of the General Staff is taken, the investigating, taking photographs and films of the artefacts and natural resources in the first and second degree naval military forbidden zones by Turkish or foreign nationals under the supervision of national organizations or national organizations are given in accordance with the provisions of the relevant law (MFZ, 1981: Articles 7 \& 13).

Those who do not comply with the permit issues, those who do not make the necessary notification, and those who use the given permits in a way to harm defense security are sentenced to imprisonment and fines unless their elephants require a heavier punishment (MFZ, 1981: Article 26).

\section{RESULTS AND DISCUSSION}

The coastal state has full control over marine scientific research activities in its own seas. It has the right to organize, authorize and direct scientific research (UNCLOS, 1982: Article 245).

There is a possibility of illegal scientific and strategic research in Turkey Seas. According to Paleri (2009), there is the possibility of illegal scientific and strategic researches at sea or under the sea. 
Research permits are granted in accordance with national legislation and international agreements to which we are a party in Turkey (ICM, 1989: Article 4). Principles of conducting research by foreigners is determined by the Council of Ministers Instruction in Turkey Seas and there is no specific law and regulation on marine research. In the Council of Ministers Instruction, there is no regulation for the implementation of national legislation except for military forbidden zones and security zones and archaeological research and excavations in any illegal situation (ICM, 1989: Article 6 ), it is clearly stated in the Council of Ministers Instruction that the given permission will be revoked (ICM, 1989: Article 5). Similarly, the principles of marine research for foreigners are determined with diplomatic notes, guides, letters and notifications in Australia (DFAT, 2012), Papua New Guinea (NRI, 2021), Japan (MFAJ, 2012) and the USA (DS, 1985). However, Norway (RRF, 2001), Spain (RD, 1981), China (DEG, 1996), South Korea (MSR 1995 (2013) \& EDM 1995 (2013)), Thailand (RPF, 2007), Colombia (DEC, 1990) and Brazil (DEC, 1988) chose to regulate the legal status of marine research through special laws and regulations, while Poland (ACM, 1991) and Russia (RAI, 1998) preferred to regulate within other maritime laws.

Foreigners who will conduct research must obtain permission in Turkey Seas. Similarly, it appears that permits are also required in the maritime jurisdictions Norway (RRF, 2001: Article 6), Spain (RD, 1981: Article 5), Poland (ACM, 1991: Articles 28 and 29), Russia (RAl, 1998: Article 25), Colombia (DEC, 1990 : Article 2), Brazil (DEC, 1988), China (DEG, 1996: Article 4), South Korea (MSR 1995 (2013): Article 6 \& EDM 1995 (2013): Article 2/2) Thailand (RPF, 2007 : Article 13), Australia (DFAT, 2012), Papua New Guinea (NRI, 2021), Japan (MFAJ, 2012) and the United States (DS, 1985).

In Turkey, the applications other than archaeological excavations and surface explorations (It is made to the Ministry of Foreign Affairs through its own embassy in the country and if abroad, Representations of the Republic of Turkey are made) can be done in person or by mail (fax, e-mail, etc.) directly to the unit in the area where research, examination, shooting and similar work will take place or to the administration to which this unit is affiliated (ICM, 1989: Article 3). However, the applications for scientific marine research need to be made regardless of the subject through diplomatic channels in Spain (RD, 1981: Article 5), Russia (RAI, 1998: Article 25), South Korea (MSR 1995 (2013): Articles 6), Thailand (RPF, 2007: Article 4), Australia (DFAT, 2012), Papua New Guinea (NRI, 2021), Brazil (DEC, 1988), Colombia (DEC, 1990: Article 2), Japan (MFAJ, 2012) and the USA (DS, 1985). It was stated that all research activities in the territorial waters of the coastal state require the explicit consent of the coastal state through diplomatic channels by Doussis (2017), too. Differently; the applications need to be done to The Norwegian Directorate of Fisheries (RRF, 2001: Article 6) in Norway, and The Minister of Transport and Maritime Economy in Poland (ACM, 1991: Articles 28 and 29). In China, while the applications for marine scientific research projects jointly conducted by foreign researchers and Chinese partners are made directly to The State Administrative Department of Marine Affairs of the People's Republic of China (DEG, 1996: Articles 3 and 4), the application for permission for the marine scientific research project to be carried out by only foreign researchers must be made through diplomatic channels to the state administrative department of marine affairs of the People's Republic of China (DEG, 1996: Articles 4 and 5).

The applications should contain the necessary information about the duration and location of research and the applicant for permission in Turkey (ICM, 1989: Article 3). While similar practice exists in Norway (RRF, 2001: Article 9), Spain (RD, 1981: Article 5), Russia (RAI, 1998: Article 25), China (DEG, 1996: Article 5) Australia (DFAT, 2012), Papua New Guinea (NRI, 2021), Japan (MFAJ, 2012), Brazil (DEC, 
1988) and Colombia (DEC, 1990: Article 4 ), there is no provision on what kind of information will be included in the permit application in Poland (ACM, 1991: Article $30)$.

In Turkey, the applications except for underwater archeology was arranged to be finalized at the latest within five days (ICM, 1989: Article 3). It is seen that the five-day period for the finalization of applications other than underwater archeology in Turkey is very short. Similarly, marine research applications must be completed within 4 months in Russia (RAI, 1998: Article 26), China (DEG, 1996: Article 5) and South Korea (MSR 1995 (2013): Article 6). In Colombia, the application must be answered within 30 days (DEC, 1990: Article 7). The duration is 15 days in matters concerning national security, and if the opinion is negative, the permit process is interrupted in Colombia, (DEC, 1990: Article 6). It has been reminded that it may take some time to respond to applications and this process requires at least two months to complete in Papua New Guinea (NRI, 2021). It is regulated that an answer will be given within two months in Norway (RRF, 2001: Article 8). In addition to these, a permit application must be made 6 months in advance in Norway (RRF, 2001: Article 8), Spain (RD, 1981: Article 5), Russia (RAI, 1998: Article 25), China (DEG, 1996: Article 5), South Korea (MSR 1995 (2013): Article 6), Australia (DFAT, 2012), Poland (ACM, 1991: Article 29), Japan (MFAJ, 2012) and Colombia (DEC, 1990: Article 3), and at least 90 days in Thailand (RPF, 2007: Article 14). There are no regulations that they should be made of the applications before at least how many days in Turkey.

In Turkey, a guide will be also appointed to persons permitted (ICM, 1989: Article 2). The features of this guide or the guide expense on the research vessel have not been clarified. Spain (RD, 1981: Articles 5 and 7), South Korea (MSR 1995 (2013): Article 10), Poland (ACM, 1991: Article 30), Australia (DFAT, 2012), Russia (RAI, 1998: Articles 25 and 28) and Brazil (DEC, 1988) apply scientists or authorized personnel as a condition of consent. Spain reserves the right to send a Spanish scientist to the preparation phase of the project if it needs to learn directly the nature of the research or the tools and materials that are intended to be used in the program (RD, 1981: Article 7). Colombia (DEC 1990: Articles 16, 17 and 18) and Norway (RRF, 2001: Article 11), on the other hand, apply it as a condition to participate in the research to allow scientists, experts, observers or authorized personnel without participating in all costs or expenses, including project or health and subsistence costs.

In Turkey, the examination, research and filming that may be harmful to our national security and national interests are not allowed. The permits of those who operate outside the work permit or whose activities are deemed harmful are canceled (ICM, 1989: Article 5). (ICM, 1989: Article 5). According to the research subject, criminal acts in the national legislation (such as administrative and judicial measures, fines and imprisonment, etc.) are applied. Similarly, Poland (ACM, 1991: Article 29) and Russia (RAI, 1998: Article 27) reserve the right or do not permit not to allow marine research projects involving marine pollution, natural and biological resources, drilling of the seabed or continental shelf, the use of explosives or construction of artificial islands or facilities. When the activities within the scope of the research permit are found to be harmful, Poland (ACM, 1991: Article 32), Russia (RAI, 1998: Article 31), Colombia (DEC, 1990: Articles 15 and 22), Norway (RRF, 2001: Articles 21 and 22) and China (DEG, 1996: Article 13) may be suspended, stoped or canceled to the research activity. In illegal cases, South Korea (MSR 1995 (2013): Article 24), Colombia (DEC, 1990: Article 24), Poland (ACM, 1991: Article 55) and China (DEG, 1996: Article 13) may impose administrative measure, administrative fine, administrative and criminal proceeding.

In Turkey, those who conduct research and analysis by obtaining permission must submit a copy of the scientific report they have prepared and a 
copy of the work they have published to the authority from which they obtained the permission (ICM, 1989: Article 7). Similarly, submission of the research report is also mandatory in Spain (RD, 1981: Article 9), Russia (RAI, 1998: Articles 28 and 29), China (DEG, 1996: Article 12), South Korea (MSR 1995 (2013): Article 10), Thailand (RPF, 2007: Articles 18, 19 and 29), Australia (DFAT, 2012), Papua New Guinea (NRI, 2021), Brazil (DEC, 1988) and Colombia (DEC, 1990: Article 16). Although there is no time limit for the submission of this report in Turkey, periods such as 90 days, 3 months, 6 months, 1 year, 2 years, 3 years are given in Spain (RD, 1981: Article 9), South Korea (EDM 1995 (2013): Article 7), Thailand (RPF, 2007: Article 29), Australia (DFAT, 2012), Brazil (DEC, 1988), Russia (RAI , 1998: Article 28) and Colombia (DEC, 1990: Article 16). In addition, there is no regulation regarding the broadcast right of the prepared publication and matters to be made about samples in Turkey. Similarly, the situation is the same in Norway (RRF, 2001), Poland (ACM, 1991: Article 30), Australia (DFAT, 2012) and Japan (MFAJ, 2012). On the other hand, taking abroad of aqua products is subject to permission in Turkey (APL, 1971: Article 25). However, the permission is required for the publication of the results of research such as natural resources or the taking off the samples and materials obtained from the country in Colombia (DEC, 1990: Article 20), Thailand (RPF, 2007: Article 28), Papua New Guinea (NRI, 2021), China (DEG, 1996: Article 10) and Russia (RAI, 1998: Article 28). 29). In South Korea, the parties are obliged to make a written agreement that includes issues such as the publication of the results of the research (EDM 1995 (2013): Article 4). In addition, researchers have the obligation to provide analysis and evaluation records of the results, or to assist in their evaluation or interpretation (MSR 1995 (2013): Article 10). In South Korea, The Ministry of Maritime Affairs and Fisheries has the authority to restrict the publication or transport of research data and results, which it considers important for national interests (MSR 1995 (2013): Article 11). In Spain, it is envisaged that data and samples that cannot be reproduced will be left at the center where the research is carried out so that the concerned parties can examine them (RD, 1981: Article 9). There is no obligation to submit a research report in Norway (RRF, 2001: Article 11) and Poland (ACM, 1991: Article 30). But, Norway (RRF, 2001: Article 11) and Poland (ACM, 1991: Article $30)$ reserve this right upon request.

\section{CONCLUSION}

As a result; although Turkey is not a party to UNCLOS, it can be said that it follows a marine scientific research policy in line with the provisions of section XIII of UNCLOS. There is a possibility of illegal scientific and strategic research in Turkey Seas. The comprehensive determination of the principles of marine scientific research in Turkish Seas will play an important role in terms of national security and national interests (political and economic interests).

Marine scientific research should be regulated by law in Turkey. With the law to be regulated, diplomatic channels or to which institution to apply depending on the subject of the research, application principles (research subject, place, duration, preliminary report, when to apply, the scientist to participate in the research and the authorized person and costs, etc.), the report principles after the research (how long it will be given, to which institution to be given, whether the publication will be made, if it will be done, the principles of permission, the right to publish the data and results of the research decided to be important in terms of national interests, the right to help in the evaluation of the report when necessary, etc.), how to follow the way about the sample and material taken (sample and material access right, process to be made on an indivisible sample or material, patent right, etc.), legal procedure principles to be applied in case of not obtaining permission or exiting the scope of the permission (suspension, stopped and cancellation of 
the permit, administrative and judicial criminal proceedings) etc. should be explained.

\section{REFERENCES}

[ACM] Act Concerning the Maritime Areas of the Republic of Poland and the Maritime Administration, 21.03.1991. Articles 28, 29, 30, 32 and 55

[APL] Aqua Products Law 1971. Official Gazette, Number 13799, Articles, 14, $21,25,29,33,36 / \mathrm{i}$ and $36 / \mathrm{n}$, Annex Article 3.

[CBD] The Convention on Biological Diversity 1992

[CGC] Regulation on Organization, Duties and Powers of the Coast Guard Command 2017. Articles: 12 and 22. Official Gazette date: 21.01.2017, Number 29995.

[DCM] Decision of the Council of Ministers 1990. Special Environmental Protection Area. Official Gazette, No. 20702.

[DCM] Decision of the Council of Ministers 2006. Special Environmental Protection Area Determined and Declared Kekova and its Environment Special Environmental Protection Area and with Göksu Delta Special Environmental Protection Area Special Environmental Protection Area Declared by the Council of Ministers dated 12/6/1988 and numbered $88 / 13019$ Boundaries and Coordinates of Fethiye-Göcek Special Environmental Protection Area whose Border Coordinates were Changed with the Decree of the Council of Ministers dated / 1/1990 and numbered 90/77. Official Gazette, Number 26371.

[DCM] Decision of the Council of Ministers 2007. Special Environmental Protection Area Determined and Announced Patara Special Environmental Protection Area and Göksu Delta Special Environmental Protection Area and Foça, which was determined and declared as a
Special Environmental Protection Area with the Decree of the Council of Ministers dated 22/10/1190 and numbered 90/1117. Changing the Boundaries of the Special Environmental Protection Area as Shown in the Attached Map and Coordinate Lists. Official Gazette, Number 26551.

[DEC] Decree No. 644 1990. Article 2, 3, 4, 6, 7, 15, 16, 17, 18, 20, 22 and 24.

[DEC] Decree No. 96.0001988. https://www.safety4sea.com/wpcontent/uploads/2014/09/pdf/2014/N ORMAN04-R1-en.pdf, Date of Access: 31.03.2021.

[DEC] Decree No.199 of the State Council of the People's Republic of China on June 18, 1996. http://www.asianlii.org/cn/legis/cen/la ws/potaofmsr735/, Date of Access: 03.04.2021.

[DFAT] Department of Foreign Affairs \& Trade 2012. A Guide to Marine Scientific Research Requests. https://www.dfat.gov.au/sites/default/f iles/marine-scientific-researchrequests.doc, Date of Access: 19.03.2021.

[DLO] Decree Law on the Organization and Duties of the Ministry of Environment and Urbanization 2011. Official Gazette, Number 27984 (Repeated), Article 13 / A-1-e.

[DS] The Department of State 1985. Foreign Research Clearance Requests. https://19972001.state.gov/global/oes/oceans/ntr vo67.html, Date of Access: 19.03.2021.

[EA] Environmental Agreements 2021. http://www.mfa.gov.tr/data/DISPOLIT IKA/Anlasmalar.pdf, Date of Access: 14.03.2021.

[EC] European Commission 2009. The Role of Maritime Zones in Promoting Effective Governance for Protection of the Mediterranean Marine Environment. Report of the Expert Group on Governance of the Mediterranean Sea. Directorate- 
General for Maritime Affairs and Fisheries Mediterranean and Black Sea Maritime Policy Mediterranean and Black Sea https://ec.europa.eu/maritimeaffairs/s ites/maritimeaffairs/files/docs/publicat ions/mediterranean_expert_group_re port_en.pdf, Date of Access: 14.03.2021.

[EC] European Commission 2013. Ethics for Researchers, Facilitating Research Excellence in FP7. Directorate-General for Research and Innovation Science in Society, Brussels.

[ECP] European Convention for the Protection of the Archaeological Heritage 1969.

[EDM] Enforcement Decree of The Marine Scientific Research Act 1995 (2013). Articles 2/2, 4 and 7.

[EL] Environmental Law 1983. Official Gazette, Number 18132 Articles 9/d, 12 and 20/k.

[ICCAT] The International Commission for the Conservation of Atlantic Tunas 1969

[ICM] Instruction of the Council of Ministers 1989. Principles to be Subject to Foreigners or Those Applying on Behalf of Foreigners with Foreign Press and Publishers Who Want to Conduct Scientific Research, Examine and Film, Number: 88/12839, Articles 2, 3, 4, 5, 6 and 7.

[MFAJ] The Ministry of Foreign Affairs of Japan 2012. The Guideline for conducting Marine Scientific Research in areas under national jurisdiction of Japan. https://www.ldf.uni-

hamburg.de/en/meteor/informationen -meteor/meteor-dokumenteinfos/diplo-antraege-spez/jp-

antrag.doc, Date of Access: 19.03.2021.

[MFZ] Military Forbidden Zones and Security Zones Law 1981. Official Gazette, Number 17552, Articles 2, $3,7,12,13,19$ and 26.
[MSR] Marine Scientific Research and the Law of the Sea: the Balance between Coastal State and International Rights.

https://www.iho.int/mtg_docs/com_w g/ABLOS/ABLOS_Conf4/GuyPaper. pdf, Date of Access: 05.10.2019

[MSR] The Marine Scientific Research Act 1995 (2013). Articles 6, 10, 11 and 24

[NRI] The National Research Institute 2021. Research Conditions and Guidelines in Papua New Guinea. https://www.wipo.int/export/sites/ww $\mathrm{w} / \mathrm{tk} / \mathrm{en} /$ databases/creative_heritage/ docs/png_guidelines.pdf, Date of Access: 19.03.2021.

[PEP] The Protocol on Environmental Protection to the Antarctic Treaty 1991

[RAI] Federal Act on The Internal Maritime Waters, Territorial Sea and Contiguous Zone of the Russian Federation (1) 1998. Articles 25, 26, 27, 28, 29 and 31.

[RD] Royal Decree 799/1981 of February on the Rules Applicable to Marine Scientific Research Activities in the Areas Subject to Spanish Jurisdiction. Articles 5, 7 and 9 . https://www.global-

regulation.com/translation/spain/148 7911/royal-decree-799-1981\%252cdated-27-february\%252c-on-rulesapplicable-to-activities-of-researchcientifico-marina-in-areas-subject-tospanish-jurisdiction.html, Date of Access: 20.03.2021.

[RPF] Regulations on the Permission for Foreign Researchers to Conduct Research in Thailand B.E. 2550 2007. Articles 4, 13, 14, 18, 19, 28 and 29.

[RRF] Regulations Relating to Foreign Marine Scientific Research in Norway's Internal Waters, Territorial Sea and Economic Zone and on the Continental Shelf 2001. Article 6

[TÜBITAK] The Scientific and Technological Research Council of Turkey 2016. Legal/Special Permit 
Information

Note.

http://tubitak.gov.tr/sites/default/files/ yasal_izin_bilgi_notu_16_05_2016.p df, Date of Access: 04.02.2019

[UN] United Nations 2010. The Law of the Sea Marine Scientific Research, United Nations Publication, Sales No. E.10.V.12. United Nations, Division for Ocean Affairs and the Law of the Sea Office of Legal Affairs United Nations, New York.

[UN] United Nations 2010. The Law of the Sea Marine Scientific Research, A Revised Guide to the Implementation of the Relevant Provisions of the United Nations Convention on the Law of the Sea. Division for Ocean Affairs and the Law of the Sea Office of Legal Affairs, United Nations, New York.

[UN] United Nations 2017. Law of the Sea, Bulletin No. 85. United Nations, Division for Ocean Affairs and the Law of the Sea Office of Legal Affairs United Nations, New York.

[UNCLOS] United Nations Convention on the Law of the Sea 1982. Articles 2, 55, 56, 57, 77, 238, 240 and 245.

Atasoy, N., Boydak, M., Çırpan, H.A., Kendigelen, A., Meriç, İ.E., Sarıkaya, A.T., Ulubelen, A., Yazıcı, H., Yıldırım, N. 2011. Science Ethics. Istanbul University Publication No: 5048.

Bardin, A. 2002. Coastal State's Jurisdiction over Foreign Vessels. Pace International Law Review, 14 (1), 27-76.

Bourtzis, T., Rodotheatos, G. 2012. Marine Research in Modern Law of the SeaLaw of the Sea Convention and Reality. The International Hydrographic Review, pp. 41-48.

Bouville, M. 2008. Crime and Punishment in Scientific Research. http://www.researchgate.net/publicati on/1916913_Crime_and_punishment in_scientific_research, Date of Access: 14.03.2021.
Caflisch, L. and Piccard, J. 1978. The Legal Regime of Marine Scientific Research and the Third United Nations Conference on the Law of the Sea. https://www.zaoerv.de/38_1978/38_1 978_3_4_a_848_901.pdf, Date of Access: 15.03 .2021 .

Christians, C.G. 2005. Ethics and Politics in Qualitative Research. In N.K.Denzin, and Y.S. Lincoln (Ed.), The Sage Handbook of Qualitative Research: Third Edition (pp. 139164). London, Thoounsand Oaks, CA. and New Delhi:Sage.

Doussis, E. 2017. Marine Scientific Research: Taking Stock and Looking Ahead. The Future of the Law of the Sea, pp. 87-103. DOI 10.1007/978-3319-51274-7_5

Drew, C.J, Hardman, M.L., Hosp, J.L. 2008. Designing and Conducting Research in Education, Chapter 3, Ethical Issues in Conducting Research. Sage Publications.

Gonsalves, M.E. 1982. International Cooperation in Marine Scientific Research and in the Development and Transfer of Marine Science and Technology in the Convention on the Law of hte Sea with Particular Reference to the Attention Paid to the Interests of Developing Countries. The UNU/IOC/UNESCO Workshop on International Cooperation in the Development of Marine Science and the Transfer of Techtïobgy in the context of the New Ocean Regime, Paris.

Güneş, Ş.A. 2007. United Nations Convention on the Law of the Sea and Protection of the Marine Environment. Ankara University Faculty of Law Journal, 56:2, 1-37.

Hubert, A.M. 2011. The New Paradox in Marine Scientific Research: Regulating the Potential Environmental Impacts of Conducting Ocean Science, Ocean Development \& International Law, 42, 329-355. 
Hubert, A.M. 2015. Marine Scientific Research and the Protection of the Seas and Oceans, Research Handbook on International Marine Environmental Law. Research Handbooks in Environmental Law series Edited by Rosemary Rayfuse, Edward Elgar Publishing.

Ilgaz, H. 2009. The Emergence of the Need to Regulate Marine Scientific Research in International Law. Journal of Naval Sience and Engineering, 5 (1), 39-48.

Kansu, E., Ruacan, Ş. 2002. Scientific Ethics: Part I, Current State of Scientific Misleading: Types, Causes, Prevention and Punishment. Archives of the Turkish Society of Cardiology, 30, 763-767.

Karapınar, N. 2015. United Nations Convention on the Law of the Sea and Some Concepts Regarding the Sea Areas. Natural Resources and Economy Bulletin, 20, ss. 13-21.

Keyuan, Z. 2003. Governing Marine Scientific Research in China, Ocean Development \& International Law, 34, 1-27. DOI: 10.1080/00908320390154565.

Küçük, M. 2003. Scientific Research and Ethics. Journal of Fiction, 2, 255-266.

Long, R. 2012. Regulating Marine Scientific Research in the European Union: It Takes More Than Two to
Tango' In: M. Nordquist, J.Norton Moore, F. Soons, and H. Kim(Eds.). The Law of the Sea Convention: U.S. Accession and Globalisation. Martinus Nijhoff Publishers, Boston.

Paleri, P. 2009. Coast Guards of the World and Emerging Maritime Threats. Ocean Policy Research Foundation, Tokyo.

Resnik, D.B. 2015. What is Ethics in Research \& Why is it Important? https://www.niehs.nih.gov/research/r esources/bioethics/whatis/index.cfm, Access: 15.03.2021.

Uçak, N.Ö., Birinci, H.G. 2008. Scientific Ethics and Plagiarism. Turkish Librarianship, 22 (2), 187-204.

Uzbay, T. 2006. Scientific Research Ethics. Periodical Publishing in Health Sciences, Turkish Medical Directory, 19-26.

Ünal, V. 2011. Report of Investigation of Current Fisheries and Socioeconomic Research in Gökova and Datça-Bozburun Special Environmental Protection Areas. Turkey's Marine and Coastal Protected Areas System Strengthening Project, Technical Report Series: 4. Ministry of Environment and Urban Development, Natural Heritage Protection General Directorate, Ankara. 